\title{
JNPH
}

Volume 6 No. 2 (Oktober 2018)

(C) The Author(s) 2018

\section{PENURUNAN TSS AIR LIMBAH LABORATORIUM RUMAH SAKIT MENGGUNAKAN METODE ELEKTROKOAGULASI}

\section{DECREASE Of COD TSS WASTE WATER HOSPITAL IN LABORATORY USING ELECTROCOAGULATION}

\author{
ARIE IKHWAN SAPUTRA \\ POLITEKNIK KESEHATAN KEMENTERIAN KESEHATAN BENGKULU, \\ JURUSAN KESEHATAN LINGKUNGAN, \\ JALAN INDRAGIRI NOMOR 3 PADANG HARAPAN BENGKULU
}

E-mail : keslingpoltek@gmail.com

\begin{abstract}
ABSTRAK
Penanganan limbah cair Laboratorium Rumah Sakit dapat dilakukan secara biologis baik aerobik maupun anaerobik, teknik terbaru yang kini telah dikembangkan untuk pengolahan limbah cair yaitu teknik elektrokoagulasi. Elektrokoagulasi merupakan proses koagulasi atau penggumpalan dengan tenaga listrik melalui proses elektrolisa untuk mengurangi atau menurunkan ion-ion logam dan partikel-partikel didalam air. Penelitian ini bertujuan untuk mempelajari pengaruh parameter tegangan, waktu kontak serta luas penampang elektroda terhadap kinerja sistem elektrokoagulasi serta menentukan kondisi operasi optimum untuk pengolahan limbah cair. Pengolahan limbah cair dilakukan secara batch, yaitu limbah ditempatkan dalam sel elektrolisa kemudian dijalankan selama waktu tertentu lalu dianalisa kadar TSS dengan memvariasikan variabel tegangan listrik, waktu kontak dan lus permukaan elektroda. Hasil yang diharapkan dalam penelitian ini adalah adanya pengaruh elektrokoaglasi dalam mengolah limbah cair rumah sakit. Berdasarkan hasil penelitian yang telah dilakukan maka didapatkan kondisi operasi yang menghasilkan efesiensi penurunan TSS didapatkan efesiensi penurunan hingga 51\% dengan variasi waktu kontak 10 menit, tegangan $24 \mathrm{~V} / 5 \mathrm{~A}$ luas penampang elektroda $200 \mathrm{~cm}^{2}$.
\end{abstract}

Kata Kunci: Elektrokoagulasi, Limbah Laboratorium, TSS

\begin{abstract}
Wastewater treatment in Hospital Laboratory can be performed bilogically, either aerobic or anaerobic, latest wastewater treatment techniques that have been developed is electrocoagulation technique. Electrocoagulation is the process of coagulation or clotting with electricity through a process of electrolysis to reduce or decrease the metal ions and particles in water. This research studying about the effect of the voltage parameters, contact time and crosssectional area of the electrode toward electrolysis system performance, and to determine the optimum operating conditions for wastewater treatment. Wastewater treatment carried out in batch, by placing waste in the electrolysis cell, then run in a certain time and then analyzed for levels of TSS by varying the voltage variable, contact time and the surface area of electrode. The expected outcome of this research is a fact that electrocoagulation is affecting the hospital
\end{abstract}


wastewater treatment. Based on the results of the research that has been done, it is found that the operating conditions that produce the efficiency of TSS decrease obtained a reduction efficiency of up to $51 \%$ with a contact time variation of 10 minutes, voltage $24 \mathrm{~V} / 5 \mathrm{~A}$ electrode cross section area of $200 \mathrm{~cm}^{2}$.

\section{Keywords: Electrocoagulation, Waste, Laboratory, TSS}

\section{PENDAHULUAN}

Rumah Sakit dan Laboratorium banyak menggunakan bahan kimia dan membuang limbah infeksius. Pada umumnya polutan yang terkandung dalam limbah Rumah Sakit dapat berupa logam berat, padatan tersuspensi atau zat organic. Teknologi alternative untuk pengolahan limbah laboratorium rumah sakit dapat dilakukan dengan menggunakan metode Elektrokoagulasi. Elektrokoagulasi merupakan proses dilewatkannya arus listrik searah pada air atau cairan yang bertujuan untuk menghilangkan polutan yang terdapat pada air tersebut dengan cara melepaskan ion logam yang terkandung pada elektodanya yang berfungsi sebagai bahan koagulant.

Berdasarkan berbagai penelitian diketahui bahwa proses elektrokoagulasi memiliki efesiensi yang tinggi dalam menghilangkan kontaminan. Faktor-faktor yang mempengaruhi proses elektrokoagulasi antara lain kuat arus (I), Tegangan (V), jarak antar elektroda mempengaruhi besar kecilnya hambatan (r), waktu kontak, derajat keasaman $(\mathrm{pH})$, dan ketebalan plat atau luas penampang elektroda. Berdasarkan faktor tersebut mempunyai hubungan yang saling mempengaruhi satau sama lain dimana antara I, $\mathrm{V}$ dan $\mathrm{r}$ merupakan satu kesatuan yang tidak dapat dipisahkan. Dalam suatu muatan listik dimnamis/mengalir faktor (r) akan sangat mempengaruhi besaran (I) sedangkan faktor (V) biasanya cenderung tetap, namum vaktor (V) dapat berubah dikarenakan terjadi perubahan pada I atau r. Pada faktor luas penampang secara tidak langsung akan mempengaruhi besaran nilai (r) dan $\mathrm{pH}$ juga akan mempengaruhi cepat rambat arus listrik sehinga dapat berpengaruh juga pada faktor (r).

Metode elektrokoagulasi bukan merupakan teknologi yang baru, akan tetapi teknologi ini belum digunakan secara luas di Indonesia. Beberapa peneliti juga mengatakan bahwa metode ini memiliki beberapa keuntungan dibandingkan dengan koagulasi yang menggunakan bahan kimia karena menggunakan bahan kimia membutuhkan biaya mahal. Metode ini menggunakan alat yang sederhana, pengoperasian yang mudah, dan mampu menghilangkan polutan dalam jumlah yang cukup besar. Maka dari itu perlu dilakaukan penelitian lebih lanjut tentang pengolahan air limbah rumah sakit dengan metode elektrokoagulasi.

\section{METODE PENELITIAN}

Salah satu metode yang sudah digunakan secara luas untuk pengolahan limbah adalah elektrokoagulasi yang memiliki keunggulan diantaranya yaitu merupakan metode yang sederhana, efisien, baik digunakan untuk menghilangkan senyawa organik, tanpa penambahan zat kimia sehingga mengurangi pembentukan residu (sludge), dan baik untuk menghilangkan padatan tersuspensi. Proses elektrokoagulasi diduga dapat menjadi pilihan metode pengolahan limbah radioaktif cair fase air alternative mendampingi metodemetode pengolahan yang lain yang telah dilaksanakan. Di Indonesia penerapan metode elektrokoagulasi untuk pengolahan limbah belum banyak dilakukan, sehingga perlu dilakukan pengkajian proses melalui percobaan-percobaan dan pengujian terhadap parameter yang berpengaruh.

Proses elektro koagulasi dapat dilakukan dengan system batch dan system alir. Elektrokoagulasi system batch adalah proses elektrokoagulasi dalam wadah yang tertutup tanpa aliran. Sedangkan 
elektrokoagulasi system flow (alir) adalah proses elektrokoagulasi dalam wadah tertutup yang mana terjadi aliran air/limbah.

Proses elektrokoagulasi menggunakan elektroda seperti aluminium ataupun besi. Besi dan aluminium merupakan sacrificialelectrode yang telah berhasil dan efektif dalam penghilangan polutan. Sacrificialelectrode adalah elektroda yang berperan sebagai anoda dan katoda. Menurut Putero, S. H, dkk (2008) faktor-faktor yang mempengaruhi proses elektrokoagulasi antara lain:

\section{Kerapatan arus listrik}

Kenaikan kerapatan arus akan mempercepat ion bermuatan membentuk flok. Jumlah arus listrik yang mengalir berbanding lurus dengan bahan yang dihasilkan selama proses.

\section{Waktu}

Menurut hokum Faraday, jumlah muatan yang mengalir selama proses elektrolisis sebanding dengan jumlah waktu kontak yang digunakan. Lama kontak terhadap elektroda adalah faktor yang sangat berpengaruh dalam proses Elektrokoagulasi, makin lama waktu kontak penempelan ionion logam pada elektroda semakin banyak COD dapat diturunkan, sehingga disimpulkan bahwa, waktu yang diperlukan oleh suatu tahap pengolahan sangat penting agar tujuan pengolahan dapat dicapai secara optimal (Carmona,2006).

\section{Tegangan}

Karena arus listrik yang menghasilkan perubahan kimia mengali rmelalui medium (logam ata uelektrolit) disebabkan adanya beda potensial, karena tahanan listrik pada medium lebih besar dari logam, maka yang perlu diperhatikan adalah mediumnya dan batasan antar logam dengan medium.

\section{Kadar keasaman $(\mathrm{pH})$}

Karena pada proses elektrokoagulasi terjadi proses elektrolisis air yang menghasilkan gas hydrogen dan ion hidroksida, dengan semakin lama waktu kontak yang digunakan, maka semakin cepat juga pembentukan gas hydrogen dan ion hidroksida, apabila ion hidroksida yang dihasilkan lebih banyak maka akan menaikan $\mathrm{pH}$ dalam larutan. $\mathrm{pH}$ larutan juga mempengaruhi kondisi spesies padalarutan dan kelarutan dari produk yang dibentuk. $\mathrm{pH}$ larutan mempengaruhi keseluruhan efisiensi dan efektifitas dari elektrokoagulasi. $\mathrm{pH}$ larutan dapat dengan mudah diubah. $\mathrm{pH}$ optimal untuk menambah efektifitas proses elektrokoagulasi yang terdapat dalam larutan berkisar antara nilai 6,5 sampai 7,5.

\section{Ketebalan plat}

Semakin tebal plat elektroda yang digunakan, daya tarik elektrostatiknya dalam mereduksi dan mengoksidasi ion logam dalam larutan akan semakin besar.

\section{Jarak antar elektroda}

Besarnya jarak antar elektroda mempengaruhi besarnya hambatan elektrolit, semakin besar jaraknya semakin besar hambatannya, sehingga semakin kecil arus yang mengalir.

\section{Alat dan bahan}

\section{Alat}

\section{Reaktor}

Reaktor yang digunakan dalam penelitian ini terbuat dari bahan acliric dan kaca yang direkatkan dengan lem kaca dan silicon untuk mencegah kebocoran. Reaktor yang digunakan terdiri dari 8 kompartement dengan dimensi masing masing PxLxT = 10x10x12 yang disusun secara berdampingan dengan rak penyangga yang terbuat dari besi siku atau anggel bar. Pada bagian bawah reaktor initerdapat saluran yang dilengkapi dengan kran yang digunakan sebagai temat pengambilan sampel yang dihubungkan dengan selang. Pada bagian atas reaktor dipasang dudukan untuk elektroda. Reaktor didesan dengan sistim terbuka dengan sekala larboratorium. 
2. Power Suplay DC

Power Suplay yang digunakan adalah adaptor DC dengan dua macam perbedaan tegangan yaitu 12 Volt dan 24 Volt. Sedangkan untuk kuat arusnya adalah 5 Ampere dan 10 Ampere. Power Suplay ini berfungsi sebagai sumber aliran listrik untuk elektrokoagulasi.

3. Multitester/Multimeter test.

Multimeter berfungsi untuk mengukur kuat arus (I) dan tegangan (V) yang dialirkan.

\section{Elektroda}

Elektroda terdiri dari anoda dan katoda. Bahan yang digunakan adalah plat alumunium dengan ukuran $5 \times 10 \times 0,1 \mathrm{~cm}$ dan 10x10x0,1 cm.

\section{Termometer}

Termometer dalam penelitian ini digunakan untuk mengukur perubahan suhu baik sebelum maupun sesudah perlakuan

\section{6. $\mathrm{pH}$ meter}

$\mathrm{pH}$ dalam penelitian ini digunakan untuk mengukur perubahan derajat keasaman baik sebelum maupun sesudah perlakuan

\section{Bahan}

1. Akrilik

Akrilik digunakan untuk membuat dasar dari reaktor. Pemilihan bahan ini dikarenakan pada bagian dasar akan dilubangi yang kemudian dipasang kran untuk pengambilan sampel.

\section{Kaca}

Kaca digunakan untuk membuat dinding dari reaktor. Pemilihan bahan kaca dikarenakan tidak bereaksi sat terjadi perubahan suhu dan $\mathrm{pH}$.

\section{Lem silicon}

Lem ini digunakan untuk merapatkan sambungan antar kaca dengan kaca dan antara kaca dengan acliric agar tidak terjadi kebocoran reaktor.

\section{Variabel Bebas}

Variabel bebas adalah variabel yang akan mempengaruhi hasil dari variabel terkait. Variabel bebas dalam penelitian ini terdiri dari:

1. Beda potensial atau tegangan arus $D C$ $(12 \mathrm{~V} / 5 \mathrm{~A}, \quad 12 \mathrm{~V} / 10 \mathrm{~A}, \quad 24 \mathrm{~V} / 5 \mathrm{~A}$ dan $24 \mathrm{~V} / 10 \mathrm{~A})$

2. Waktu Kontak di reaktor $\left(\mathrm{T}_{1}\right.$ dan $\left.\mathrm{T}_{2}\right)$

3. Luas penampang elektroda $(5 \times 10 \times 0,1 \mathrm{~cm}$ dan $10 \times 10 \times 0,1 \mathrm{~cm})$

\section{Pelaksanaan penelitian}

Langkah kerja percobaan

1. Siapkan reaktor telah buat sebelumnya.

2. Tutup semua kran yang ada pada bagian bawah reaktor

3. Isi reaktor dengan sampel menggunakan backer glas $1000 \mathrm{ml}$ sebanyak 1000 $\mathrm{ml} /$ reaktor

4. Pemasangan elektroda $12 \mathrm{~V} / 5 \mathrm{~A}$

a. Pada kelompok tegangan $12 \mathrm{~V} / 5 \mathrm{~A}$ ini siapkan 5 lempeng elektroda ukuran $5 \times 10 \times 0,1 \mathrm{~cm}$ dan 5 Lempeng degan ukuran 10x10x0,1 cm

b. Susun jarak anatar elektroda $2,5 \mathrm{~cm}$ dengan susunan (Positip-NegatipPositip-Negatip- Positip).

c. Hubungkan dengan Power Suplay $12 \mathrm{~V} / 5 \mathrm{~A}$ dengan menggunakan kabel dengan pengait jepit buaya.

5. Pemasangan elektroda $12 \mathrm{~V} / 10 \mathrm{~A}$

a. Pada kelompok tegangan $12 \mathrm{~V} / 10 \mathrm{~A}$ ini siapkan 5 lempeng elektroda ukuran $5 \times 10 \times 0,1 \mathrm{~cm}$ dan 5 Lempeng degan ukuran 10x10x0,1 cm

b. Susun jarak anatar elektroda $2,5 \mathrm{~cm}$ dengan susunan (Positip-NegatipPositip-Negatip- Positip). 
c. Hubungkan dengan Power Suplay $12 \mathrm{~V} / 10 \mathrm{~A}$ dengan menggunakan kabel dengan pengait jepit buaya.

6. Pemasangan elektroda $24 \mathrm{~V} / 5 \mathrm{~A}$

a. Pada kelompok tegangan $24 \mathrm{~V} / 10 \mathrm{~A}$ ini siapkan 5 lempeng elektroda ukuran $5 \times 10 \times 0,1 \mathrm{~cm}$ dan 5 Lempeng degan ukuran 10x10x0,1 cm

b. Susun jarak anatar elektroda $2,5 \mathrm{~cm}$ dengan susunan (Positip-NegatipPositip-Negatip- Positip).

c. Hubungkan dengan Power Suplay 24V/10A dengan menggunakan kabel dengan pengait jepit buaya.

7. Pemasangan elektroda $24 \mathrm{~V} / 10 \mathrm{~A}$

a. Pada kelompok tegangan $12 \mathrm{~V} / 10 \mathrm{~A}$ ini siapkan 5 lempeng elektroda ukuran $5 \times 10 \times 0,1 \mathrm{~cm}$ dan 5 Lempeng degan ukuran 10x10x0,1 cm

b. Susun jarak anatar elektroda $2,5 \mathrm{~cm}$ dengan susunan (Positip-NegatipPositip-Negatip- Positip).

c. Hubungkan dengan Power Suplay 12V/10A dengan menggunakan kabel dengan pengait jepit buaya.

8. Pastikan semua elektroda sudah terhubung pada power suply

9. Isi masing-masing kompartement dengan air sampel sebanyak 1 liter

10. Hidupkan power suply dengan menghubungkan ke sumber listrik AC dan catat waktu mulainya

11. Pada kelompok reaktor dengan waktu kontak $\mathrm{T}_{1}$ jika waktu kontak telah mencapai yang ditentukan matikan sumber listriknya

12. Ukur suhu air dalam reaktor dengan menggunakan termometer dan catat kenaikan suhunya.

13. Perhatikan pada bagian reaktor setelah terbentuk flok maka ambil sampel dengan cara membuka kran pada bagian bawah dan mengambil sampelnya sebanyak $100 \mathrm{ml}$.

14. Analisis parameter COD

15. Lakukan hal yang sama untuk waktu kontak $\mathrm{T}_{2}$.

\section{HASIL PENELITIAN}

Percobaan yang telah dilaksanakan ini menghasilkan data penurunan kandungan TSS yang dapat dilihat pada table berikut:

Tabel 1. Penurunan Kandungan TSS Pada limbah Rumah Sakit.

\begin{tabular}{|c|c|c|c|c|c|}
\hline \multirow[b]{2}{*}{$\begin{array}{c}\text { Waktu } \\
\text { Kontak } \\
\text { (menit) }\end{array}$} & \multicolumn{2}{|c|}{ Daya listrik } & \multirow{2}{*}{\multicolumn{2}{|c|}{$\begin{array}{l}\text { Elektro- TSS } \\
\text { da }(\mathrm{cm})(\mathrm{mg} / \mathrm{l})\end{array}$}} & \multirow[b]{2}{*}{$\begin{array}{c}\% \\
\text { REMO } \\
\text { VAL }\end{array}$} \\
\hline & $\begin{array}{c}\text { Tegan } \\
\text { gan } \\
\text { (Volt) }\end{array}$ & $\begin{array}{c}\text { Kuat } \\
\text { arus } \\
\text { (Ampe } \\
\text { re) }\end{array}$ & & & \\
\hline & Pretre & eatment & & 210 & 0 \\
\hline \multirow{8}{*}{5} & \multirow{4}{*}{12} & \multirow{2}{*}{5} & $5 \times 10$ & 112 & 46,7 \\
\hline & & & $10 \times 10$ & 115 & 45,2 \\
\hline & & \multirow{2}{*}{10} & $5 \times 10$ & 120 & 42,9 \\
\hline & & & $10 \times 10$ & 107 & 49,0 \\
\hline & \multirow{4}{*}{24} & \multirow{2}{*}{5} & $5 \times 10$ & 110 & 47,6 \\
\hline & & & $10 \times 10$ & 121 & 42,4 \\
\hline & & \multirow{2}{*}{10} & $5 \times 10$ & 116 & 44,8 \\
\hline & & & $10 \times 10$ & 101 & 51,9 \\
\hline \multirow{8}{*}{10} & \multirow{4}{*}{12} & \multirow{2}{*}{5} & $5 \times 10$ & 134 & 36,2 \\
\hline & & & $10 \times 10$ & 120 & 42,9 \\
\hline & & \multirow{2}{*}{10} & $5 \times 10$ & 126 & 40,0 \\
\hline & & & $10 \times 10$ & 109 & 48,1 \\
\hline & \multirow{4}{*}{24} & \multirow{2}{*}{5} & $5 \times 10$ & 105 & 50,0 \\
\hline & & & $10 \times 10$ & 96 & 54,3 \\
\hline & & \multirow{2}{*}{10} & $5 \times 10$ & 111 & 47,1 \\
\hline & & & $10 \times 10$ & 98 & 53,3 \\
\hline
\end{tabular}

\section{PEMBAHASAN}

\section{Pengaruh Waktu Kontak Terhadap Penurunan TSS}

Berdasarkan hasil percobaan diketahui bahwa waktu kontak memberikan dampak 
terhadap beberapa parameter TSS. Untuk mengetahui hubungan atau korelasi waktu kontak sebagai salah satu variabel bebas yang dipilih terhadap konsentrasi zat tersuspensi maka dibuat grafik dibawah ini:

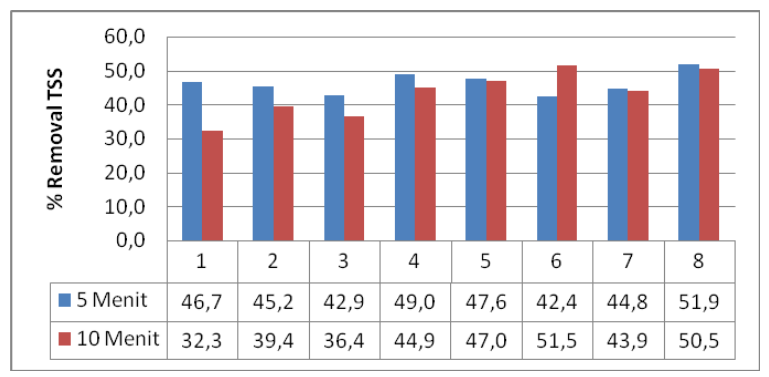

\section{Gambar 1 Persentase Removal TSS Terhadap Waktu}

Berdasarkan Gambar 1 di atas maka dapat diketahui bahwa terjadi penurunan kandungan atau konsentrasi TSS setiap kenaikan tegangan dan kuat arus. Fenomena ini menunjukan kesesuian hasil penelitian dengan hukum Faraday, yaitu kenaikan arus berbanding lurus dengan jumlah logam anoda sebagai sumber koagulan yang terlarutkan. Tren penurunan dapat dengan jelas teramati melalui grafik di atas. Proses penurunan TSS terjadi melalui pembentukan koagulan $\mathrm{Al}(\mathrm{OH})_{2}$ yang dihasilkan oleh anoda $\mathrm{Al}^{3+}$ dan ion $\mathrm{OH}^{-}$yang berasal dari molekul $\mathrm{H}_{2} \mathrm{O}$. Koagulan $\mathrm{Al}(\mathrm{OH})_{2}$ ini selanjutnya mengadsorbsi polutan-polutan yang ada ke dalam rongga molekulnya.

Proses penurunan TSS dapat difahami karena TSS adalah polutan yang berada dalam bentuk tersuspensi. Bila suatu materi tersuspensi maka material tersebut berbentuk solid dengan ukuran tertentu. Material solid ini dapat dengan mudah teradsorbsi ke dalam koagulan $\mathrm{Al}(\mathrm{OH})_{2}$ atau teradsorbsi ke dalam gelembung udara. Hasil adsorbsi ini akan terpisahkan ke atas (terflotasi) sehingga terjadi penurunan konsentrasi TSS di dalam air limbah.

Secara teoritis bahwa semakin besar tegangan dan kuat arus yang digunakan maka semakin besar pelepasan gas hidrogen dan gas oksigen yang terkandung dalam air, berarti semakin banyak gas hidrogen yang terbentuk maka semakin banyak gelembung yang dihasilkan maka semakin banyak flok yang terikat pada rongga gelembung tersebut sehingga terjadi penurunan TSS.

Pada kelompok waktu 10 menit terjadi penurunan kandungan TSS tertinggi terjadi pada perlakuan 6 sebesar 51,5\%. Sedangkan pada perlakuan 8 penurunan hingga $50,5 \%$ yang sebelumnya adalah $198 \mathrm{mg} / \mathrm{liter}$. Sedangkan penurunan terendah terjadi pada perlakuan 3 dengan tingkat penurunan sebesar $36,4 \%$. Sedangkan pada kelompok pada kelompok waktu 5 menit penurunan tertinggi terjadi pada pada perlakuan 8 dengan penurunan menjadi $51,9 \%$ dari sebelumnya $210 \mathrm{mg} /$ liter. Sedangkan pada penurunan terendahnya pada perlakuan 6 sebesar $42,4 \%$.

\section{Pengaruh Tegangan, Kuat Arus, dan Luas Penampang Elektroda Terhadap Penurunan TSS}

Penurunan kandungan TSS tidak hanya dipengaruhi oleh waktu kontak saja, akantetapi teganggan, kuat arus dan luas penampang elektroda juga mempengaruhi penurunan kandungan TSS pada proses elektrokoagulasi ini yang dapat dilihat dari Gambar 2 dan 3 berikut:

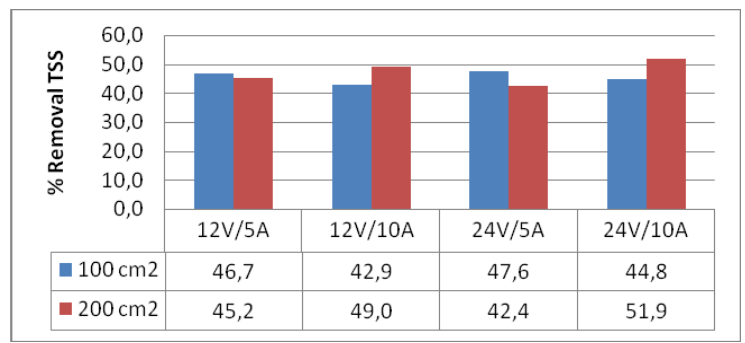

Gambar 2 Penurunan TSS Terhadap Tegangan, Kuat Arus, Dan Luas Elektroda Pada Waktu Kontak 5 Menit. 


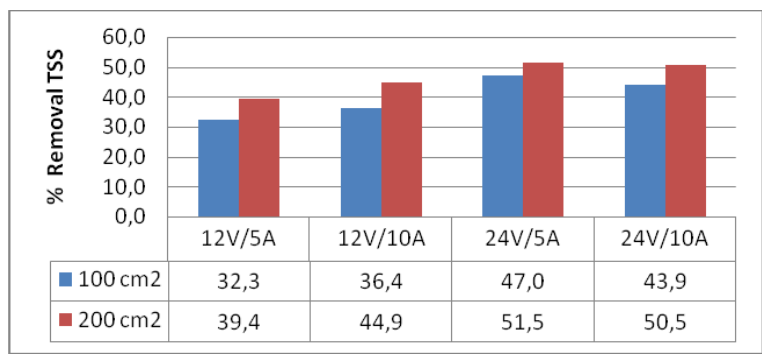

Gambar 3 Penurunan TSS Terhadap Tegangan, Kuat Arus, dan Luas Elektroda Pada Waktu Kontak 10 Menit.

Pengaruh tegangan listrik dalam mempengaruhi penurunan kandungan TSS dalam proses elketrokoagulasi pada waktu kontak 5 menit maupun 10 menit dapat kita lihat perbedaannya antara tegtangan $24 \mathrm{~V}$ dengan $12 \mathrm{~V}$. Berdasarkan gambar 4.7 dan 4.8 diatas maka dapat dinyatakan bahwa perbedaan tegangan mempengaruhi penurunan kandungan TSS dalam air limbah.

Kuat arus juga memiliki peranan dalam menurunkan kandungan TSS yang dapat diamati dari gambar 4.7 dan 4.8 diatas bahwa terjadi perbedaan penurunan kandungan TSS dalam setiap kenaikan kuat arus dari 5A menjadi 10 Ampere.

Hubungan antara tegangan listrik dan kuat arus dalam menurunkan kandungan TSS dimungkinkan karenan semakin tinggi kuat arus dan teganggannya akan mempercepat waktu pelepasan ion $\mathrm{Al}^{3+}$ dan $\mathrm{OH}-$ yang berfungsi sebagai koagulan. Pengaruh kuat arus dan tegangan juga memberikan dampak jumlah gelembung yang terbentuk yang akan membawa pengotor ke permukaan dan mengikatnya sehingga menurunkan kandungan TSS pada air limbah.

\section{KESIMPULAN}

Waktu Kontak 10 menit memebrikan efesiensi removal TSS tertinggi yaitu 54,3\%, sedangkan tegangan yang memberikan efesiensi removal tertinggi pada penurunan kandungan TSS adalah tegangan 24 Volt, sedangkan pada Variabel Kuat Arus didapatkan hasil yang efektif pada kuat arus 10 Amper. Begitu juga luas penampang elektroda dengan ukuran 10x10x0,1 cm memberikan efesiensi tertinggi pada penurunan TSS.

\section{SARAN}

Kepada peneliti selanjutnya diharapkan agar berupaya lebih mengembangkan dan memperdalam bahasan tentang penurunan TSS air limbah laboratorium Rumah Sakit dengan menggunakan desain penelitian yang berbeda.

\section{DAFTAR PUSTAKA}

Ardhani, A.F. dan Ismawati, D. (2007), "Penanganan Limbah Cair Rumah Pemotongan Hewan dengan Metode Elektrokoagulasi”. Makalah Penelitian Jurusan Teknik Kimia, Fakultas Teknik,Universitas Diponegoro, Semarang

Bayramoglu, M., Eyvaz, M. Kobya, M. and Senturk,E., 2006. "Technical and Economic Analysiso of Electrocoagulation for the Treatment of Poultry Slaughterhouse Wastewater", Separation and Purification Technology, vol.51, p.404

Carmona, M., Khemis, M., Leclerc, J.P., and Lapicque, F., 2006. "A Simple Model To Predict The Removal Of Oil Suspensions From Water Using The Electrocoagulation Technique". Chemical Engineering Science, 61: 1237 $-1246$

Holt, P.K., Barton, G.W., and Mitchell, C.A., 1999, "Electrocoagulation as A Wastewater Treatment, The Third Annual Australian Environmental Engineering Research Event" 23-26 November Castlemaine, Victoria

Lin, Shundar. 2001, "Water and Wastewater Calculation Manual”, McGraw-Hill, USA

Metcalf, Eddy. 1991, "Wastewater Engineering" third edition, McGraw Hill Inc. New York

Mukimin, A. 2006, Pengolahan Limbah 
Industri Berbasis Logam Dengan Teknologi Elektrokoagulasi Flotasi, Tesis, Universitas Diponegoro, Semarang.

Ni'am, M.F., Othman, F., Sohaili, J., dan Fauzia, Z., 2007, "Removal of COD and Turbidity to Improve Wastewater Quaity Using Electrocoagulation Technique", The Malaysian Journal of Analytical Sciences, Vol 11 No 1, 198-205

P. Hari,B., dkk (2010), “ Pengolahan Limbah Cair Tekstil Menggunakan Proses Elektrokoagulasi Dengan Sel Al-Al", Prosiding Seminar Nasional Teknik Kimia, ISSN 1693-4393.

Susetyaningsih, R. Dkk (2008), "Kajian Proses Elektrokoagulasi Untuk Pengolahan Limbah Cair", Seminar Nasional IV, SDM Teknologi Nuklir, YLH, Yogyakarta ISSN 1978-0176

Sutanto, dkk (2011), "Penurunan Kadar Logam Berat dan Kekeruhan Air Limbah Menggunakan Proses Elektrokoagulasi”, Jurnal Ilmiah Elite Elektro, Vol. 2, no. 1, Hal. 1-6, Jakarta 